\title{
Happy 70th birthday, Professor Sarkyt E. Kudaibergenov
}

Article

Accepted Version

Khutoryanskiy, V. (2021) Happy 70th birthday, Professor Sarkyt E. Kudaibergenov. Polymers for Advanced

Technologies, 32 (7). pp. 2636-2638. ISSN 1042-7147 doi: https://doi.org/10.1002/pat.5156 Available at https://centaur.reading.ac.uk/93757/

It is advisable to refer to the publisher's version if you intend to cite from the work. See Guidance on citing.

To link to this article DOI: http://dx.doi.org/10.1002/pat.5156

Publisher: John Wiley

All outputs in CentAUR are protected by Intellectual Property Rights law, including copyright law. Copyright and IPR is retained by the creators or other copyright holders. Terms and conditions for use of this material are defined in the End User Agreement.

\section{www.reading.ac.uk/centaur}

\section{CentAUR}

Central Archive at the University of Reading

Reading's research outputs online 


\title{
Happy $70^{\text {th }}$ birthday, Professor Sarkyt E. Kudaibergenov
}

\author{
Vitaliy V. Khutoryanskiy ${ }^{1,2}$ \\ ${ }^{1}$ Reading School of Pharmacy, University of Reading, Whiteknights, PO Box 224, RG66AD, Reading, \\ United Kingdom, v.khutoryanskiy@reading.ac.uk
}

${ }^{2}$ Al-Farabi Kazakh National University, 71 al-Farabi Av., 050040, Almaty, Kazakhstan

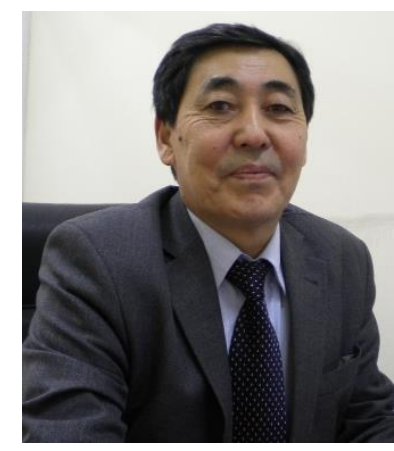

In May 2021 the polymer science community of Kazakhstan, numerous former students and collaborators will celebrate the 70th anniversary of Prof Sarkyt E. Kudaibergenov. Prof S.E. Kudaibergenov is a prominent Kazakh polymer scientist, known for his research into water-soluble polymers, polyelectrolytes, polymer complexes, hydrogels, polymerstabilised colloids, catalysis by polymers and stimuli-responsive materials for various applications. This essay aims to present some highlights of research career of Prof Kudaibergenov with a particular emphasis on his most significant original contributions to polymer science.

Prof Sarkyt E. Kudaibergenov was born on $20^{\text {th }}$ May 1951 in Semipalatinsk region of Kazakh Soviet Socialist Republic, which at that time was a part of Soviet Union. He studied chemistry at Kazakh State University in Almaty from 1968 to 1973; then in 1973-1976 worked as an engineer in the Laboratory of Physicochemical Methods in the Faculty of Chemistry at Kazakh National University. One of his research projects was related to the studies of low-temperature zone of the front of hydrocarbon flames, which resulted in his first publication [1]. In 1980 he joined the Laboratory of Physical Chemistry of Polymers led by Prof E.A. Bekturov at the Institute of Chemical Sciences as a Junior Researcher and this move led him to a lifelong passion in polymer science. His became involved in the studies of hydrodynamic properties of polyelectrolytes based on vinylethynylpiperidoles-4 resulted in several important publications [2, 3] and successful defence of a thesis with the award of a candidate of chemical sciences degree (equivalent to PhD) in 1981. Following his PhD defence he began expanding the areas of research interests and made contributions to the studies of interactions between poly(ethylene glycols) and alkali metals and ammonium thiocyanates [4], catalytic properties of complexes of poly(2-vinyl pyridine) and palladium [5], amphoteric properties of polyelectrolyte complexes [6] and other studies of metal-polymer complexes [7].

In 1985 he got promoted to a position of Senior Researcher and in 1989 to a position of Leading Researcher. In 1991 he defended a habilitation dissertation on the studies of the complex formation reactions involving synthetic polyampholytes at Moscow State University (Russia) and was awarded a degree of Doctor of Chemical Sciences. In 1994 he received a title of Professor of Chemistry. Two particular highlights of his research in these years are the discovery of the "isoelectric effect" at the isoelectric point of polyampholytes [8] and formation of polyelectrolyte complexes at the dimeric interface between two immiscible liquids [9].

In the early nineties he established collaboration with researchers of Kazakh State National University and in 1996 was appointed as a Professor and Head of research group in the Department of Macromolecular Chemistry of this University. In these years he turned his research interests to hydrogen-bonded interpolymer complexes [10], interpolyelectrolyte complexes [11], interactions of polyampholytes with disperse particles [12], stimuli-responsive hydrogels $[13,14]$ and functional membranes [15]. In 1998 he was a visiting professor of Waseda University (Japan) in the group of Prof 
E. Tsuchida, where he researched ion conductivity of gels based on poly(divinyl ether of diethyleneglycol) in mixtures with lithium perchlorate [16].

In 1999 he has established and became the Director of the Institute of Polymer Materials and Technologies (IPMT) as a private research organisation in Almaty (Kazakhstan), which he continues to lead until present. The main research activities of this Institute are focused on the fundamental studies in the field of chemistry and physics of polymers, application of polyfunctional polymers of synthetic and natural origin in oil industry as well as nanomaterials and nanotechnologies. Some of the highlights of Prof Kudaibergenov's research in IPMT include the studies of DNA containing polyelectrolyte complexes [17], films prepared at the interfaces of immiscible liquids [18], theoretical studies of salt bonds in polyampholyte chains [19], and hydrophobically modified polybetaines as pour point depressants [20]. In 2002-2003 Prof Kudaibergenov was a visiting professor of Kwangju Institute of Science and Technology (South Korea), where he researched into the development of synthetic strategies and studies the properties of novel polycarbobetaines [21].

Throughout his entire research career Prof Kudaibergenov was always open for new opportunities and collaborative links with numerous researchers worldwide. He has made numerous research contributions to various fields of polymer chemistry, materials science and nanotechnology. Some examples of these collaborative projects include the studies of Langmuir-Blodgett films [22], carbon nanotubes [23] and iron oxide photo-catalyst [24].

Since Prof Kudaibergenov was born in the region that is not far from the Semipalatinsk Nuclear Test Site, he was always feeling an obligation and desire to help with remediation of this radionuclidecontaminated soil. He became an honorary professor of Semipalatinsk Shakarim State University in 2002, initiated the organisation of the Centre for Chemical Ecological Problems in this University and supervised research activities into the use of polymers and their complexes as soil structuring agents to prevent migration of radionuclides and to facilitate their extraction from contaminated soil $[25,26]$.

In the most recent decade Prof Kudaibergenov continued active research and turned his attention to a number of new interesting projects, including polymer-protected and hydrogel-immobilised gold nanoparticles [27] and their catalytic applications [28], macroporous cryogels [29], hydrophobically modified polymers and hydrogels [30], application of water-soluble polysaccharides in oil extraction [31] and drug delivery [32, 33].

The breadth of his research interests, desire to explore new avenues of polymer and material science, openness for new collaborations and exceptional hardworking ability continuously lead to new ideas, developments and plans. Despite many successful developments and contributions of Prof S.E. Kudaibergenov in different areas of physical chemistry of polymers, his most favourite topic is the study of amphoteric polymers (polyampholytes). He has been studying polyampholytes since 1979 and published a number of reviews and a fundamental single-author monograph «Polyampholytes: Synthesis, Characterization and Application» (Springer, 2002).

He has co-authored 18 monographs and textbooks published in Russian, Polish and English, over 400 research articles and reviews, with more than 100 of which are in international peer-reviewed journals. His research was recognised through many awards, including the State Prize of the KazSSR in the field of Science and Technology (1986), "Parasat" award as the most published and cited abroad Kazakhstani author (2010), a breastplate "For merits in the development of science of the Republic of Kazakhstan" from the Ministry of Science and Education of the Republic of Kazakhstan (2012) and K.I. Satpayev Prize for the development of specialty polymers for application in petrochemistry and nanotechnology (2019). 
He has also organised many international research meetings and workshops, including traditional International Workshop "Specialty polymers for environment protection, oil industry, bio-, nanotechnology and medicine", held in Semey (2006), Almaty (2008), Almaty (2011), Issyk-Kul, Kyrgyzstan (2013), Semey (2015), Almaty (2017), Karaganda (2019). Numerous former students of Prof S.E. Kudaibergenov currently work as academics and researchers in many universities, research and industrial organisations of Kazakhstan and some other countries.

On behalf of all collaborators, international colleagues, numerous current and former students I congratulate Prof Sarkyt Kudaibergenov with his $70^{\text {th }}$ Anniversary and wish him all the best in his further research activities and personal life.

This special issue of Polymers for Advanced Technologies aims to celebrate Prof Kudaibergenov's anniversary and contains contributions from many of his current and former students, international colleagues and collaborators.

\section{References}

1. G.I. Ksandopulo, A.A. Sagindykov, S.E. Kudaibergenov, Z.A. Mansurov. Low-temperature zone of the front of hydrocarbon flames: V. Profiles of the concentrations of atomic hydrogen and peroxide radicals at the front of propane-air flames. Combustion, Explosion and Shock Waves. 1975, V.11(6), P. 714-719.

2. S.E. Kudaibergenov, S.S. Shajakhmetov, E.A. Bekturov, S.R. Rafikov. Hydrodynamic properties of amphoteric copolymers. Doklady Akademii Nauk SSSR, 1979, V.246 (1), P.141-143

3. E.A. Bekturov, S.S. Shajakhmetov, S.E. Kudaibergenov. Hydrodynamic properties of poly-1,2,5trimethyl- and 2,5-dimethyl-4-vinylethynilpyperidol-4 hydrochlorides in solution. Polymer. 1980, V.21 (7), P.787-790

4. E.A Bekturov, S.E Kudaibergenov, V.Z Ushanov, S.S Saltybaeva. Interaction of poly (ethylene glycol) with thiocyanates of alkali metals and ammonium. Die Makromolekulare Chemie, Rapid Communications 1985, V.6 (7), P.515-519

5. E.A Bekturov, S.E Kudaibergenov, D.V. Sokolskii, A.K. Zharmagametova. Poly (2-vinylpyridine) complexes of palladium as catalysts of unsaturated alcohol hydrogenation. Die Makromolekulare Chemie, Rapid Communications 1986, V.7 (4), P.187-191

6. J. Koetz, B. Philipp, V. Sigitov, S. Kudaibergenov, E.A. Bekturov. Amphoteric character of polyelectrolyte complex particles as revealed by isotachophoresis and viscometry. Colloid and Polymer Science, 1988, V. 266 (10), P. 906-912.

7. E.A. Bekturov, S.E. Kudaibergenov, G.S. Kanapyanova, S.S. Saltybaeva. Mössbauer Spectroscopic Studies of Complexes of Fe (III) with Nitrogen Containing Polymers. Polymer Journal 1991, 23 (4), 339-342.

8. E.A. Bekturov, S.E. Kudaibergenov, S.R. Rafikov. The properties of solutions and complex formation reactions of amphoteric polyelectrolytes. Uspekhi Khimii (Russian Chemical Reviews) 1991, 60 (4), 835-851.

9. S.E Kudaibergenov, R.E. Khamzamulina, E.A.Bekturov, L.A. Bimendina, V.A. Frolova, M.Zh. Askarova. Polyelectrolyte complex formation on a dimeric interface. Macromol. Rapid Commun. 1994, V.15, P.943-947.

10. S.E Kudaibergenov, Z.S. Nurkeeva, G.A. Mun, B.B. Ermukhambetova, A.T. Akbauova. Interpolymer complexes of (co) poly (vinyl ethers) of glycols and poly (carboxylic acids). Macromol. Chem. Phys. 1995, V.196, P.2203-2209.

11. S.E. Kudaibergenov, Z.S. Nurkeeva, V.B. Sigitov, K.Zh. Akimbekova, V.Zh. Ushanov. Interpolyelectrolyte complexes of poly[4-(but-3-en-1-ynyl)-1-methylpiperidin-4-ol] with poly(carboxylic acids). Macromol. Chem. Phys. 1997, V.198, P. 183-191. 
12. K.B. Musabekov, N.K. Tusupbaev, S.E. Kudaibergenov. Interaction of synthetic polyampholytes with disperse particles. Macromol. Chem.Phys. 1998, V.199 (3), P.401-408.

13. S.E Kudaibergenov, Z.S. Nurkeeva, G.A. Mun, B.B. Ermukhambetova, I.K. Nam. Temperatureresponsive swelling and deswelling of the copolymers from vinyl ether of ethylene glycol and butyl vinyl ether. Macromol. Rapid Commun. 1995, V.16, P.855-860.

14. S.E. Kudaibergenov, V.B. Sigitov, Swelling, shrinking, deformation and oscillation of polyampholyte gels based on vinyl 2-aminoethyl ether and sodium acrylate. Langmuir, 1999, V.15(12), P. 4230-4235.

15. S.E. Kudaibergenov, Z.S. Nurkeeva, G.A. Mun, V.V. Khutoryanskiy, A.D. Gazizov. Design of composite films and ultrathin membranes of interpolymer complexes. Polym. Adv. Technol. 2000, V.11, P.15-19.

16. S.E. Kudaibergenov, K. Miyatake, S. Takeoka, E. Tsuchida, E.A. Bekturov, lon-conductivity of Gels based on Poly(divinyl ether of diethyleneglycol) and Lithium Perchlorate, Eurasian Chem. Tech. Journal, 2004, No.6, P.285-291.

17. V.A. Izumrudov, M.V. Zhiryakova, S.E. Kudaibergenov, Controllable stability of DNA-containing polyelectrolyte complexes in water-salt solutions. Biopolymers, 1999, V.52(2), P.94-108.

18. Gazizov, A.D. Zhumadilova, G.T. Bimendina, L.A. Kudaibergenov, S.E., Interpolymer complexes of some vinyl copolymers in a solution and on the boundary of two liquid phases. Polymer, 2000, V.41(15), P.5793-5797.

19. S.B. Moldakarimov, E.Yu. Kramarenko, A.R. Khokhlov, S.E. Kudaibergenov. Formation of Salt Bonds in Polyampholyte Chains. Macromol. Theory and Simulations. 2001, V.10, Issue 8, P. 780-788.

20. A.G. Didukh, R.B. Koizhaiganova, L.A. Bimendina, S.E. Kudaibergenov. Synthesis and Characterization of Novel Hydrophobically Modified Polybetaines as Pour Point Depressants. J. Appl. Polym. Sci. 2003, V.92, P.1042.

21. J.G. Noh, Y.I. Sung, K.E. Geckeler, S.E. Kudaibergenov. Synthesis, characterization, and stimuli-sensitive properties of novel polycarbobetaines. Polymer, 2005, V.46, P.2183-2190.

22. S.A. Yeroshina, N.Kh. Ibrayev, S.E. Kudaibergenov, F. Rullens, M. Devillers, A. Laschewsky. Spectroscopic properties of mixed Langmuir-Blodgett films of rhodamine dyes and poly $(\mathrm{N}, \mathrm{N}-$ diallyl-N-octadecylamine-alt-maleic acid). Thin Solid Films, 2008, v.516, p.2109-2114.

23. R.B. Koizhaiganova, He Jin Kim, S. Kudaibergenov, Mu Sang Lee. In-situ polymerization of 3hexylthiophene with double-walled carbon nanotubes: Studies of the conductive nanocomposite. J. Appl. Polym. Sci. 2010, V.115, P. 2448-2454.

24. J. Johnson, N. Bakranov, M. Moniruddin, R. Iskakov, S. Kudaibergenov, N. Nuraje. Spontaneous polarization field-enhanced charge separation for an iron oxide photo-catalyst. New Journal of Chemistry, 2017, V.41, No. 24, P. 15528-15532.

25. L.K. Orazzhanova, M.G. Yashkarova, L.A. Bimendina, S.E. Kudaibergenov. Binary and ternary polymer-strontium complexes and the capture of radioactive strontium- 90 from the polluted soil of the Semipalatinsk Nuclear Test Site. Journal of Applied Polymer Science, 2003, 87 (5), 759-764

26. S.E.Kudaibergenov, L.A.Bimendina, M.G.Yashkarova, L.K.Orazzhanova, Application of Interpolymer Complexes of Novel Poly(ampholyte-electrolyte) as Soil Structuring Agents and for Extraction of Radioactive Strontium, Research Journal of Chemistry and Environment, 2006, V. 10 (2), P.2-4.

27. N. Dolya, O. Rojas, S. Kosmella, B. Tiersch, J. Koetz, S. Kudaibergenov. "One-Pot" in situ Formation of Gold Nanoparticles within Poly(acrylamide) Hydrogels. Macromol. Chem. Phys. 2013. DOI: $10.1002 / \operatorname{macp} .201200727$. 
28. R. Tursunova, N. Yesmurzayeva, B. Selenova, S. Kudaibergenov. Preparation and Catalytic Activity of Gold-Copper Bimetallic Nanoparticles Stabilized by Poly(N-vinyl-2-pyrrolidone) and Immobilized Onto Inorganic Supporters. J. Inorg. Organomet. Polym. Mater. 2016, V.26(6), P.1259-1263. DOI 10.1007/s10904-016-0416-5.

29. S.E. Kudaibergenov, G.S. Tatykhanova, A.N. Klivenko Complexation of Macroporous Amphoteric Cryogels based on N,N-dimethylaminoethylmethacrylate and Methacrylic Acid with Dyes, Surfactant, and Protein. J. Appl. Polym. Sci. 2016. V. 133, P. 43784-1 - 43784-9 (DOI: 10.1002/app.43784).

30. G. Toleutay, E. Su, S. Kudaibergenov, O. Okay. Highly stretchable and thermally healable polyampholyte hydrogels via hydrophobic modification. Colloid Polym. Sci. 2020, V. 298, No.3, P.273-284.

31. S. Kudaibergenov, N. Nuraje, Zh. Adilov, D. Abilkhairov, R. Ibragimov, I. Gusenov, A. Sagindykov. Plugging behavior of gellan in porous saline media. J. Appl. Polym. Sci. 2015, V.132, No.2, DOI: 10.1002/app.41256.

32. G.K. Abilova, D.B. Kaldybekov, G.S. Irmukhametova, D.S. Kazybayeva, Zh.A. Iskakbayeva, S.E. Kudaibergenov, V.V. Khutoryanskiy. Chitosan/Poly (2-ethyl-2-oxazoline) Films with Ciprofloxacin for Application in Vaginal Drug Delivery. Materials 2020, V.13 (7), P.1709.

33. L.E. Agibayeva, D.B. Kaldybekov, N.N. Porfiryeva, V.R. Garipova, R.A. Mangazbayeva, R.I. Moustafine, I.I. Semina, G.A. Mun, S.E. Kudaibergenov, V.V. Khutoryanskiy. Gellan gum and its methacrylated derivatives as in situ gelling mucoadhesive formulations of pilocarpine: in vitro and in vivo studies. Int. J. Pharm., 2020, 577, 119093. 